\title{
A NEW SPECIES AND A NEW COMBINATION IN FRIESODIELSIA ( ANNONACEAE) OF BORNEO
}

\author{
I. M. TURNER
}

\begin{abstract}
A new species of Friesodielsia (Annonaceae), Friesodielsia formosa, is described from Borneo. A large woody climber of lowland forests, the species has been collected from Sabah, Sarawak and Kalimantan. A new combination in Friesodielsia is made for Oxymitra grandifolia Merr. which is resurrected from the synonymy of Friesodielsia latifolia (Hook.f. \& Thomson) Steenis. The name Oxymitra grandifolia is lectotypified.

Keywords. Friesodielsia, Indonesia, Malaysia, Oxymitra, typification.
\end{abstract}

\section{INTRODUCTION}

Friesodielsia Steenis (Annonaceae) is a palaeotropical genus of some 50 or so species (Kessler, 1993). The Asian species, which may well be generically distinct from the African species (Kessler, 1993; Richardson et al., 2004), are woody climbers. In reviewing material of Friesodielsia from Borneo it became clear that there were quite a number of collections representing an undescribed species, and this new species is described below.

The name Friesodielsia was published by van Steenis (1949) as an avowed substitute for Oxymitra (Blume) Hook.f. \& Thomson, a later homonym of a genus of liverworts. Later van Steenis (1964) transferred most of the species described in Oxymitra to Friesodielsia. One Bornean Oxymitra species, O. grandifolia Merr., was not transferred, presumably because Sinclair (1951) had reduced it to synonymy with another species. This species is distinct, however, and I propose a new combination in Friesodielsia for it.

\section{A New Species of Friesodielsia}

The new species of Friesodielsia is easily distinguished from other Bornean species. It is generally a more robust plant with typically larger leaves (more than $20 \mathrm{~cm}$ long) and longer petioles (15 mm or more) than the other species. The lamina is more or less glabrous and does not have an auriculate base, which distinguishes it from any other large-leaved species of Friesodielsia in Borneo. The flowers of the new species

Research Associate, Royal Botanic Gardens, Kew, UK, and Research Associate, Singapore Botanic Gardens, Singapore. Address for correspondence: Fairfield, Pett Level Road, Winchelsea Beach, East Sussex TN36 4ND, UK. E-mail: j_trop_ecol@yahoo.co.uk 
have outer petals that are thin (chartaceous to subcoriaceous), flat and unridged whereas the other species have outer petals relatively thick (coriaceous) and often distinctly triquetrous or rhomboidal in cross-section in the upper part or with a distinct central longitudinal ridge. The monocarps of the new species are larger (more than $3 \mathrm{~cm}$ long) than any other species in Borneo (less than $3 \mathrm{~cm}$ long). Reference to a revision of the genus in the Malay Peninsula (Sinclair, 1955) and herbarium material from neighbouring areas, particularly the Philippines, failed to reveal any Friesodielsia species similar to the new species.

\section{Friesodielsia formosa I.M.Turner, sp. nov. Figs 1, 2.}

A congeneribus borneensibus foliis maioribus, petiolis longioribus, petalis exterioribus tenuibus applanatis, monocarpis maioribus differt. - Type: Borneo, Kalimantan, Central Kalimantan, headwaters of S. Kahayan, 5 km north-west of Tumbang Sian logging camp $\left(0^{\circ} 35^{\prime} \mathrm{S}, 113^{\circ} 25^{\prime} \mathrm{E}, 150 \mathrm{~m}\right.$ alt.), 26 iv 1988, J.S. Burley et al. 832 (holo K; iso E, L, SAR, SING).

Large woody climber. Twigs drying black or rather dirty brown, striate or latticed, with raised brown lenticels, darker and smoother when young, more or less glabrous. Leaves chartaceous, glabrous, glaucous beneath, drying dark brown or rather patchy dull brown above, reddish or purplish brown beneath, with midrib and laterals dark brown or black, lamina oblong-elliptic to oblong-obovate, $17-33 \times 6-10 \mathrm{~cm}$, base obtuse, often slightly decurrent to petiole but not auriculate, with paired glands in lamina margin, apex obtuse to shortly acuminate, midrib sunken above and prominent beneath, lateral veins c.15 pairs, immersed above, prominent beneath, tertiary venation distinct from both surfaces in dry leaves, more so from above, less distinctly scalariform than other species in Borneo. Petiole 15-22 mm long, 2-3 mm thick, drying dark, shallowly furrowed. Inflorescences single- to few-flowered. Flowers fragrant, pedicel 15-40 $\mathrm{mm}$ long, c.0.5 mm thick, drying black, striate, tiny medial bract c. $1 \mathrm{~mm}$ long; sepals free, tending to reflex at anthesis, broadly ovate, 6-10 $\times 8 \mathrm{~mm}$, apex blunt, drying black or dark brown; outer petals yellow or cream, reflexing at anthesis, thin and flat, ovate lanceolate, 40-50 $\times 15-20 \mathrm{~mm}$, drying very dark brown, sparse covering of tiny brown adpressed hairs on both surfaces, pale spots externally, inner petals ovate, $10-11 \times 8 \mathrm{~mm}$, apex acute, drying black with sparse very tiny brown adpressed hairs; stamens many, c. $2 \mathrm{~mm}$ long, connective apex truncate, polygonal (mostly 5-sided); carpels c.6-10, c.2 mm long, hairy, stigmas globose, hirsute. Fruiting pedicel to $4.5 \mathrm{~cm}$ long, $2 \mathrm{~mm}$ thick; monocarps 1-7, ripening orange-red, ellipsoidal, 4-5 $\times 1.5-2 \mathrm{~cm}$, drying dark brown, deeply and irregularly wrinkled, wrinkles with rounded not sharp-edged margins, glabrous, apiculus scarcely discernible; stipe green, drying black, $2-3 \mathrm{~cm}$ long. Seed 1, c. $3 \times 1.5 \mathrm{~cm}$.

FIG. 1. Photograph of the holotype of Friesodielsia formosa I.M.Turner. (C) The Board of Trustees of the Royal Botanic Gardens, Kew. Reproduced with the consent of the Royal Botanic Gardens, Kew. 


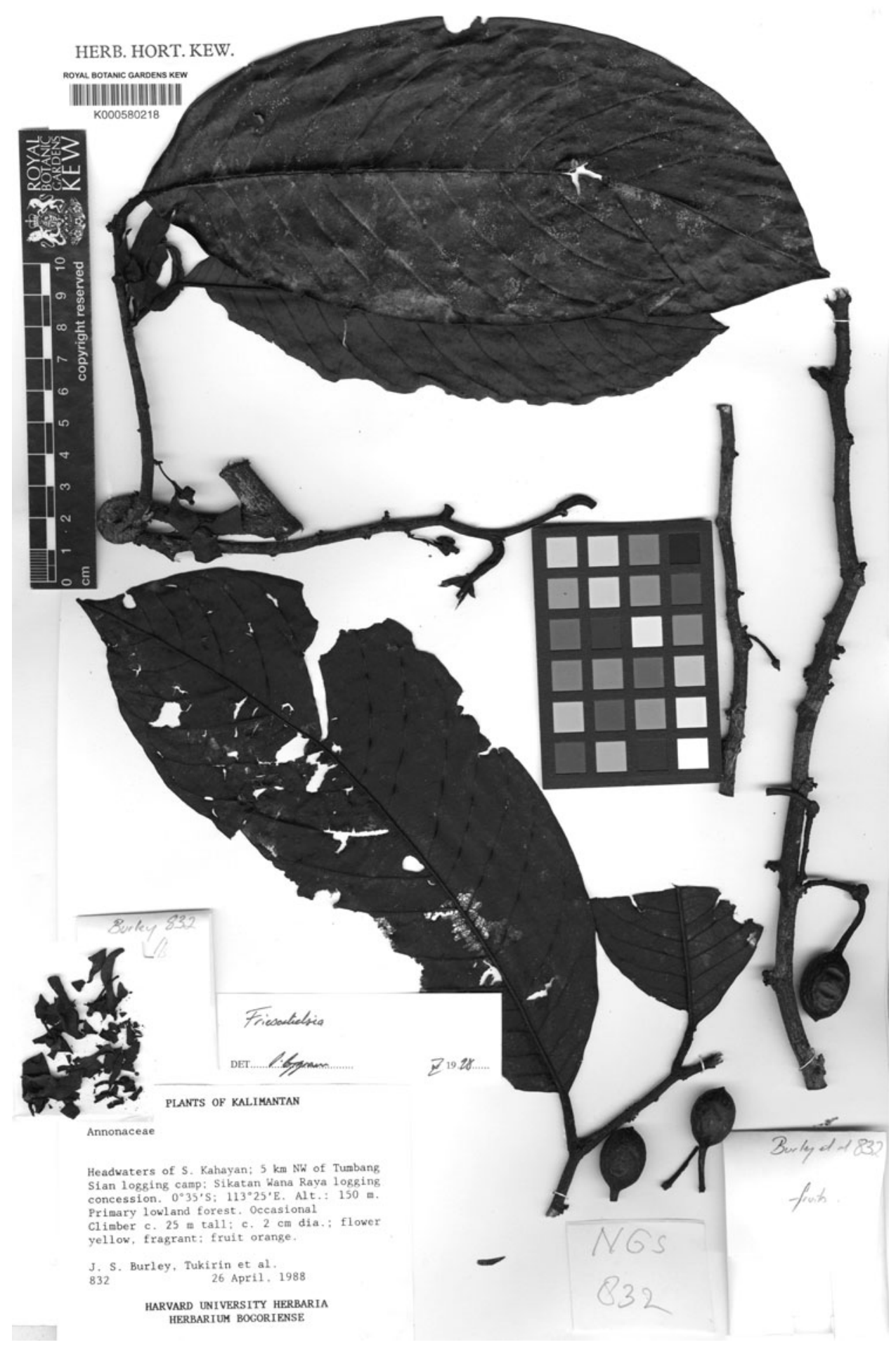




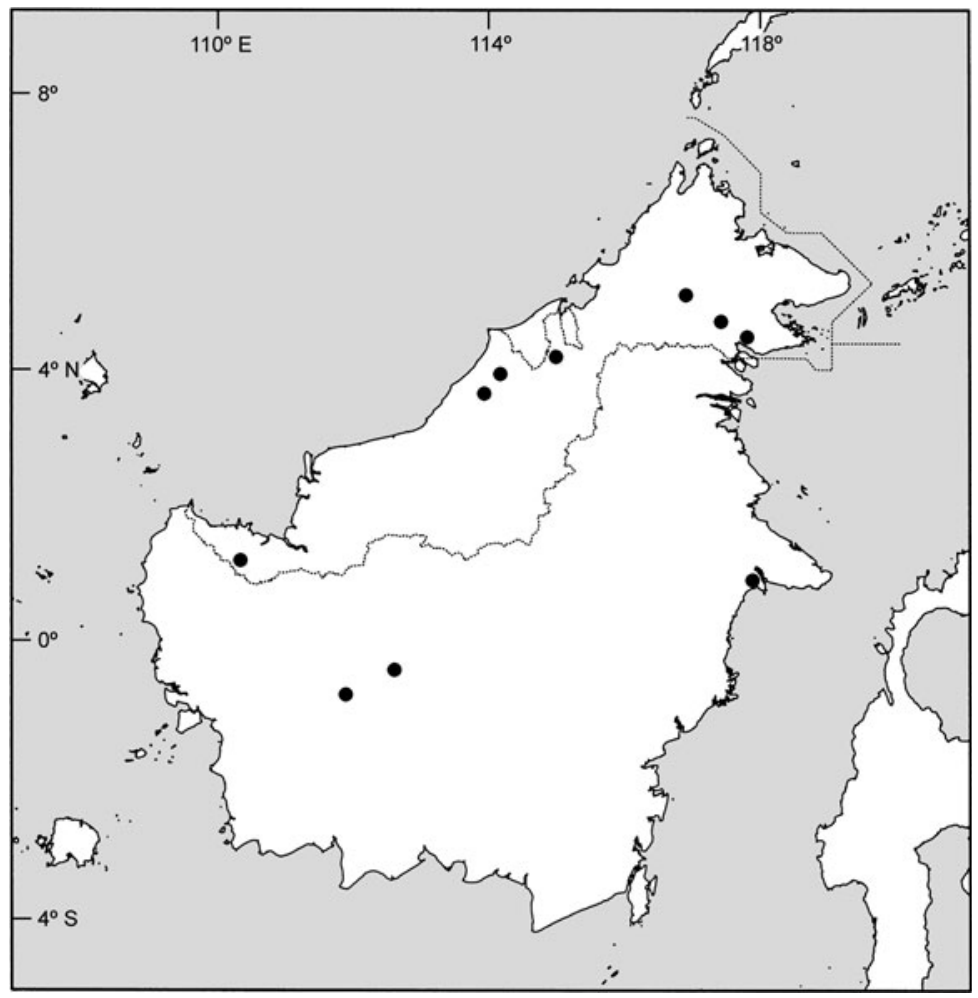

FIG. 2. Map showing the localities of collections of Friesodielsia formosa in Borneo.

Distribution. Endemic to Borneo where it is known from Sabah, Sarawak, and Central and East Kalimantan.

Habitat. Lowland forest to $200 \mathrm{~m}$, including that on limestone.

Proposed IUCN conservation status. The only data available for a conservation assessment come from the herbarium sheets seen which give no information on the relative abundance of the species at the collecting localities. However, given the number of collections and their wide geographic distribution in Borneo, there seems no immediate cause for concern for the species and the proposed category is Least Concern (IUCN, 2001).

Etymology. In Latin, formosus means handsome or beautiful; so the epithet reflects the attractive form of this species.

Additional specimens examined. Malaysia. Sabah: Sandakan Division, Tongod District, Ulu Sungai Kawaye, Gunong Rara, 23 x 1984, Amin et al. SAN 107334 (SAN); Tawau Division, Tawau District, Merotai Besar, 20 ix 1962, Aban Gibot SAN 31322 (SAN); Tawau Division, Tawau District, Luasong, NBT Camp, 10 iii 1977, Fedilis Krispinus SAN 82198 (SAN). Sarawak: Limbang Division, Limbang District, Tanjong Long Amok, Sg Ensungei, Ulu 
Malamit, 9 ix 1980, R. George et al. S 42357 (K, SAR); Miri Division, Miri District, Niah, between mouth of Sungei Sebalah and Gunong Subis, 30 xi 1966, J.A.R. Anderson S 27588 (SAR, SING); Miri Division, Marudi District, Long Karangan, Ulu Sg Sekiwa, Btg. Tinjar, 2 ix 1974, S. Tong S 35028 (K, SAR); Samarahan Division, Serian District, Bukit Selebor, Lobang Mawang, Tebakang Road, 29 ix 1968, Ilias Paie S 28103 (K, SAR, SING).

IndONESIA. Kalimantan: Central Kalimantan, Sintang, HPH km 70, 17 iv 1994, Church et al. 969 (A[×2], BO, K, SING); Central Kalimantan, Sintang, HPH km 71-73, 12 iv 1994, Mahyar et al. $860(\mathrm{~A}[\times 2], \mathrm{BO}, \mathrm{SING})$; Central Kalimantan, Sintang, 23 iv 1994, Mahyar et al. 1062 $(\mathrm{A}[\times 2], \mathrm{BO}, \mathrm{SING})$; Central Kalimantan, Sintang, 23 iv 1994, Church et al. 1067 (A, BO, K, SING); East Kalimantan, East Kutei, Gunung Sebrat, south of Sangkulirang, 28 vii 1951, A.J.G.H. Kostermans 5975 (BO, K, SING), 30 vii 1951, A.J.G.H. Kostermans 5924 (BO, K).

\section{A New Combination in Friesodielsia}

Merrill (1922) described Oxymitra grandifolia from fruiting material collected by M. Ramos in the vicinity of Sandakan in Sabah. Sinclair (1951) reduced the name Oxymitra grandifolia to a synonym of $O$. latifolia Hook.f. \& Thomson (三Friesodielsia latifolia (Hook.f. \& Thomson) Steenis), a species from the Malay Peninsula. Sinclair only saw fruiting material. However, some flowering material of the Bornean plant is now available and it becomes clear that Oxymitra grandifolia is distinct from Friesodielsia latifolia. Friesodielsia latifolia has flowers with thick concave outer petals which lack a central ridge but have a markedly triquetrous apex; the outer petals of Oxymitra grandifolia are thinly coriaceous and flat in the upper part, not triquetrous apically, but with a clear central ridge. It is therefore necessary to resurrect Oxymitra grandifolia from synonymy and provide a new combination in Friesodielsia.

Friesodielsia grandifolia is actually closer to Friesodielsia borneensis (Miq.) Steenis. It shares the minutely granular appearance to the lower lamina surface (not found in Friesodielsia latifolia), but the leaves of $F$. grandifolia are generally larger than those of $F$. borneensis, the flower pedicels are shorter and the fruits of $F$. grandifolia dry a darker brown.

Merrill designated M. Ramos 1910 as the type of Oxymitra grandifolia with the specimens distributed from the Bureau of Science in Manila. Unfortunately both the Manila and Sandakan herbaria have been lost to fire in the intervening years. The only extant duplicate of the type collection I have found is in Herbarium Bogoriense and this I designate lectotype. There are duplicates of paratypes in various herbaria.

Friesodielsia grandifolia (Merr.) I.M.Turner, comb. nov.

Oxymitra grandifolia Merr., J. Straits Branch Roy. Asiat. Soc. 85: 179 (1922).

- Type: Borneo, Sabah, Sandakan, ix-xii 1920, M. Ramos 1910 (lecto, designated here, BO (sheet no. BO-13593592)).

In describing Oxymitra latifolia, Hooker \& Thomson (1855) referred to a collection from Penang by Phillips in W. Hooker's herbarium. Hooker's herbarium was 
incorporated into the Kew collection in 1867. There is a sheet from the Hooker herbarium among the Kew specimens that is labelled 'Penang Uvaria grandifolia mss.', and also annotated with a reference to Oxymitra latifolia in Flora of British India (Hooker \& Thomson, 1872). Although this sheet does not have any indication of the collector's identity it is considered the holotype in the absence of any other original material. Sinclair (1955) referred to two sheets from the Hooker herbarium in the Kew collection, but the second sheet labelled 'Dom. Phillips 1824' came from the Bentham herbarium, not Hooker's.

Friesodielsia latifolia (Hook.f. \& Thomson) Steenis, Blumea 12: 360 (1964).

Oxymitra latifolia Hook.f. \& Thomson, Fl. Ind. 145 (1855). - Type: Malay Peninsula, Penang, s. dat., s. coll. [W.E. Phillips?] s.n. (holo, K ex Herb. Hooker).

\section{ACKNOWLEDGEMENTS}

I am grateful to the Arnold Arboretum, Forest Research Institute of Malaysia and Singapore Botanic Gardens for financial support for this research and to the Royal Botanic Gardens, Kew, for facilitating the endeavour. Dr J. F. Veldkamp (L) kindly translated the diagnosis into Latin.

\section{REFERENCES}

Hooker, J. D. \& Thomson, T. (1855). Flora Indica. London: W. Pamplin.

НоoкеR, J. D. \& Тномson, T. (1872). Flora of British India, vol. 1. London: L. Reeve and Co.

IUCN (2001). IUCN Red List Categories and Criteria, Version 3.1. IUCN Species Survival Commission. Gland, Switzerland and Cambridge, UK: IUCN.

Kessler, P. J. A. (1993). Annonaceae. In: Kubitzki, K., Rohwer, J. G. \& Bittrich, V. (eds) The Families and Genera of Vascular Plants 2: 93-129. Berlin: Springer.

Merrill, E. D. (1922). New or noteworthy Bornean plants. J. Straits Branch Roy. Asiat. Soc. 85: 151-201.

Richardson, J. E., Chatrou, L. W., Mols, J. B., Erkens, R. H. J. \& Pirie, M. D. (2004). Historical biogeography of two cosmopolitan families of flowering plants:

Annonaceae and Rhamnaceae. Phil. Trans. Roy. Soc. London, ser. B 359: 1495-1508.

Sinclair, J. (1951). Notes on Bornean Annonaceae. Sarawak Mus. J. 5: 597-609.

Sinclair, J. (1955). A revision of Malayan Annonaceae. Gard. Bull. Straits Settlem., ser. 3 14: 149-516.

Steenis, C. G. G. J. van (1949 ['1948']). Remarks on some generic names used for Malaysian phanerogams I. Bull. Jard. Bot. Buitenzorg, sér. 3 17: 457-464.

Steenis, C. G. G. J. van (1964). An account of the genera Richella A. Gray and Oxymitra (B1.) Hook.f. \& Th. (Annonaceae). Blumea 12: 353-361. 